\title{
ポリープ状異型腺筋腫と子宮内膜異型増殖症が共存し子宮鏡下に切除した一例
}

\author{
高木病院産婦人科 ${ }^{1)}$ 、病理部 ${ }^{2)}$

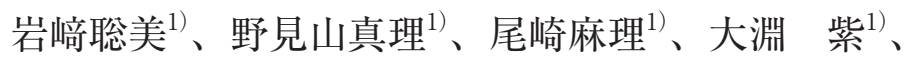 \\ 有馬 薰 ${ }^{1)}$ 、小島加代子 ${ }^{1)}$ 、山浐文朗 ${ }^{2)}$ 、岩坂 剛 $^{1)}$
}

\section{Atypical Polypoid Adenomyoma Coexistent with Atypical Endometrial Hyperplasia Treated with Hysteroscopic Transcervical Resection: Case Report}

\author{
Satomi Iwasaki ${ }^{1}$, Mari Nomiyama ${ }^{1}$, Mari Ozaki ${ }^{1}$, Yukari Ohbuchi ${ }^{1)}$, \\ Kaoru Arima $^{1)}$, Kayoko Kojima ${ }^{1)}$, Fumio Yamasaki ${ }^{2)}$, Tsuyoshi Iwasaka ${ }^{1)}$ \\ Takagi Hospital, Department of Obstetrics and Gynecology ${ }^{1)}$, Department of Pathology ${ }^{2)}$
}

\begin{abstract}
:
An atypical polypoid adenomyoma (APAM) is a benign mixed epithelial and mesenchymal tumor. Histologically, an APAM features a biphasic proliferation of atypical endometrial glands within myofibromatous stroma. To emphasize the potential risk for myometrial invasion, APAM with markedly complex glands is designated "atypical polypoid adenomyoma of low malignant potential" (APA-LMP). We report a case of a 27-year-old infertile woman with an atypical polypoid adenomyoma coexistent with atypical endometrial hyperplasia. She underwent hysteroscopic transcervical resection followed by medroxyprogesterone acetate therapy. After a complete response was achieved, she received clomiphene therapy and subsequently underwent in vitro fertilization-embryo transfer (IVF-ET). Although APAM is a benign tumor, a persistent lesion or recurrence is frequently observed. Occasionally, APAM coexists with endometrial hyperplasia or carcinoma. Clinical management of APAM has not been elucidated; however, fertility conservation should be considered if it is followed by careful observation.
\end{abstract}

Key words: atypical polypoid adenomyoma of low malignant potential, atypical endometrial hyperplasia, fertility preservation

\section{【緒 言】}

不妊女性の10～15\%に子宮内膜ポリープ、粘膜下 筋腫などの子宮内腔病変が発見される ${ }^{1)}$ 。今回我々 は不妊治療を目的に受診した若年女性に、ポリープ 状異型腺筋腫 (atypical polypoid adenomyoma、 APAM）と子宮内膜異型増殖症（atypical endometrial hyperplasia、AEH）が共存した症例を経験したの で報告する。

\section{【症例】}

患者：27歳女性、既婚 BMI $24.7 \mathrm{~kg} / \mathrm{m}^{2}$

主訴：月経不順、挙児希望

妊娠分娩歴：0 経妊 0 経産
月経歴：初経 12 歳、周期不順、過多月経あり。希 発月経のため 20 歳頃から中用量ピル内服やカウフ マン療法などの治療を不定期に受けていた。

既往歴：特記すべきことなし

現病歴：挙児希望を主訴に当科を受診した。半年 間、婦人科を受診しておらず、最終月経は不明で、 当科初診の 2 週間前に 1 日のみ性器出血があっ た。初診時、経臸超音波検査にて子宮内膜厚は $13.8 \mathrm{~mm}$ で、三層構造を認めなかった。右卵巣に 径 $5 \mathrm{~cm}$ 大で内部全体に点状エコーを有する襄胞 性腫瘤を認めた。血液検査で血色素量 $9.3 \mathrm{~g} / \mathrm{dl}$ と 貧血を認めた。腫瘍マーカーはCEA: $1.1 \mathrm{ng} / \mathrm{ml}$ 、 CA19-9: $28 \mathrm{U} / \mathrm{ml} 、 \mathrm{CA} 125: 46.7 \mathrm{U} / \mathrm{ml}$ とA125の 軽度上昇を認める以外は基準值内であった。右卵 


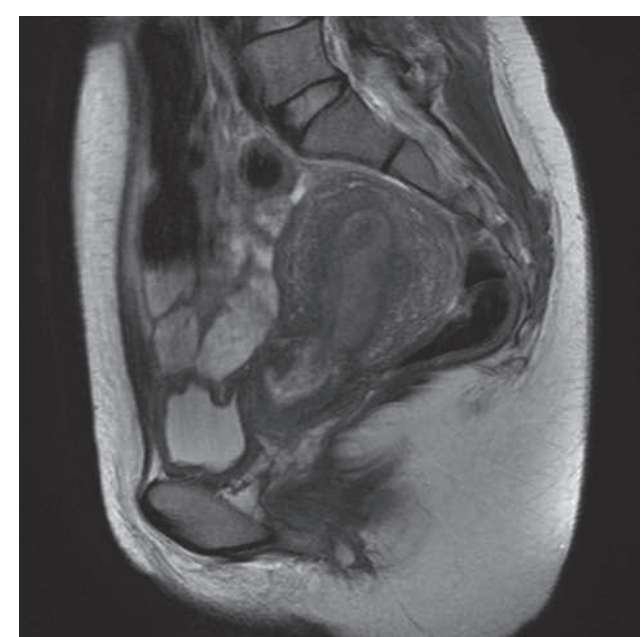

図1a T2強調画像

子宮内腔を占拠し、子宮頸部に突出するような腫 瘤性病変を認める。

巣腫瘤の精查目的で造影MRI検査を行ったとこ ろ、子宮内腔を占拠し、子宮頸部に突出するよう な腫瘤性病変を認めた。腫瘤は子宮内膜より低信 号で、増強効果を認め、子宮内膜ポリープの可能 性が疑われた（図 1 )。卵巣の腫瘤は後日消失し、 機能性囊胞であった。子宮頸部および内膜細胞 診は除性であった。Chemical curettage目的で 中用量ピルを21日間投与した。内服開始20日目 より性器出血を認め、10日間以上持続したため受 診。子宮鏡検査は灌流不良のため視野不明瞭。 Sonohysterographyで子宮内腔を占拠するポリー プを認めた。子宮内膜組織診を施行したところ、 性器出血が増量し止血しなかったため、同日、緊 急子宮鏡下経頸管的切除（transcervical resection: TCR）を行った。

子宮鏡下手術所見：腰椎麻酔下にストルッ社製 $26 \mathrm{Fr}$ (外径 $8 \mathrm{~mm}$ ） モノポーラレゼクトスコープ

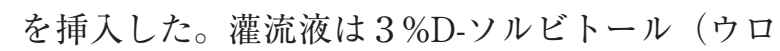
マチック ${ }^{\circledR}$ ) 用い、自動灌流装置（ストルッ、 エンドマット ${ }^{\mathrm{TM}}$ ) により子宮内を定圧灌流、持続 吸引した。電極は切除用ループ電極を、パワーソ ースはCOVIDIEN, Vallylab ${ }^{\mathrm{TM}}$ を使用し、切開 40W、凝固20Wで手術を行った。子宮腔内の観察 所見で、子宮底から発生した $4 \times 2 \times 2 \mathrm{~cm}$ の分 葉した有茎性腫瘤を認めた（図 2 )。茎部に出血 点を認め、凝固止血した。体下部に径 $2 \mathrm{~cm}$ の広 基性腫瘤、近傍に小型のポリポイド状に分葉化し た隆起性病変を認めた。すべての病変を切除した。 術後経過は問題なく、術後 2 日目に退院となった。 病理組織所見：子宮底の有茎性腫瘤、体下部の広 基性腫瘤の組織像では、内膜腺の増殖と平滑筋性

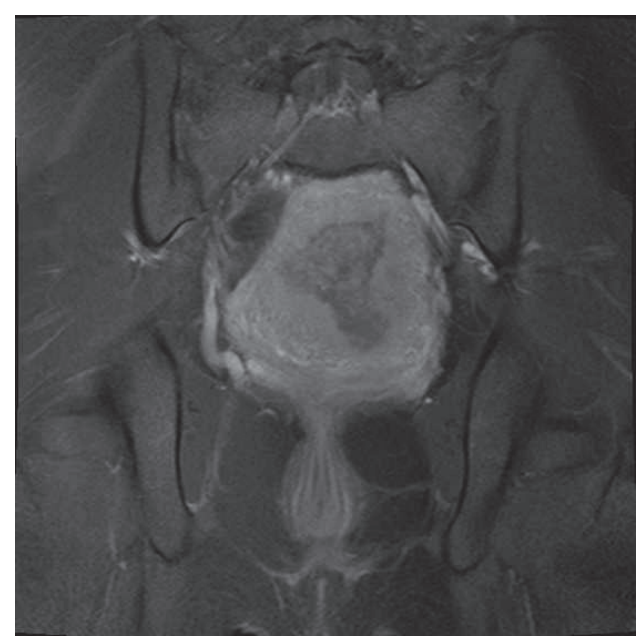

図1b 脂肪抑制Gd造影 $T 1$ 強調画像

子宮内腫瘤は増強効果を認めるが小さな腺腔構造 を認めない。

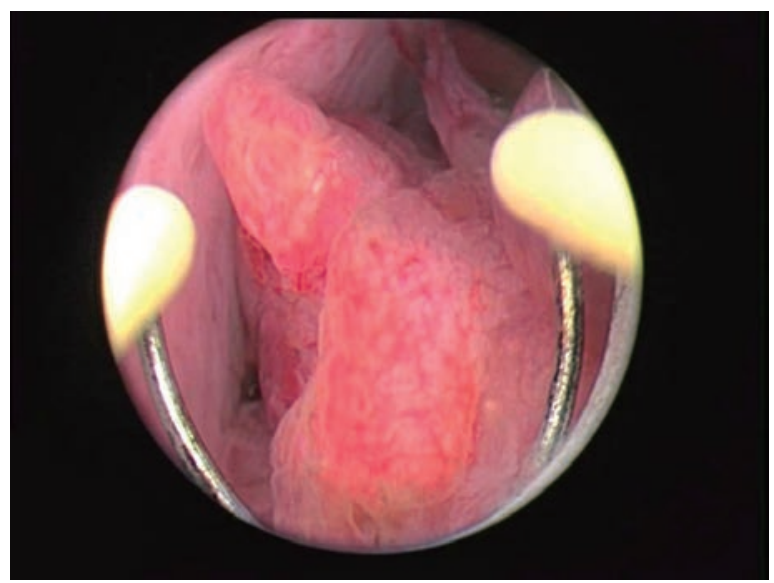

図2子宮鏡下手術所見

子宮底から発生した $4 \times 2 \times 2 \mathrm{~cm}$ の分葉した有茎性腫瘤を認める。

間質の介在を認めた。内膜腺は密に増殖し、軽〜中 等度の細胞異型を認めた。部分的にback to backや 穊状構造を呈し、高分化類内膜腺癌に匹敵するほど の構造異型を認めた。APAMの特徵の一つとされる 桑実様化生を伴っていた（図 3 )。構造異型が強い ことから、 atypical polypoid adenomyoma of low malignant potential (APA-LMP) と診断した。小 型のポリポイド状隆起性病変の組織像では、軽〜 中等度の細胞異型を伴う内膜腺の密な増殖と back to backや笁状構造を認め、atypical endometrial hyperplasia (AEH) と診断した。以上より APALMPとAEHの共存と診断した。

術後経過：TCR後15日目に子宮内膜全面掻爬を 施行した。病理組織所見は前回のTCR標本に類 似する組織像で、軽〜中等度の細胞異型を伴う内 膜腺が広範かつ密に増殖していた（図 4)。back to backや所々では穊状構造を呈するに至り、桑 


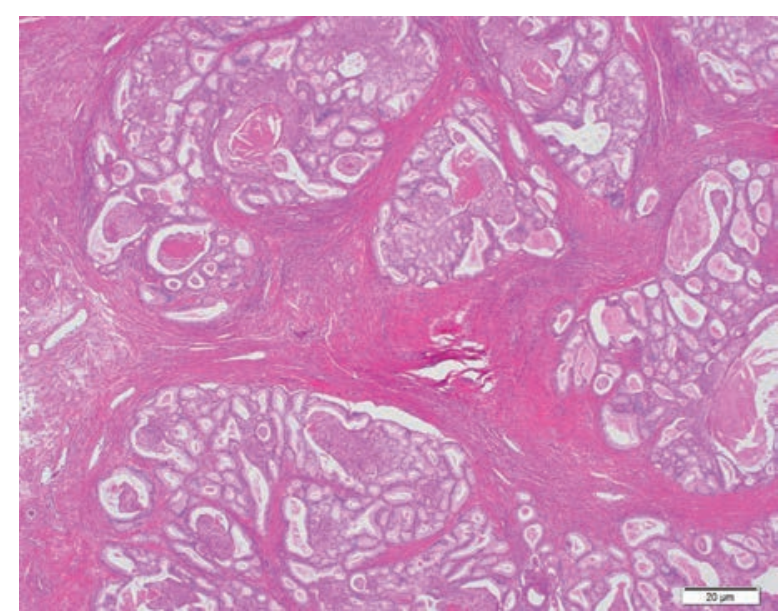

図3a 病理組織所見 (40倍 HE染色)

内膜腺の增殖と平滑筋性間質の介在を認める。

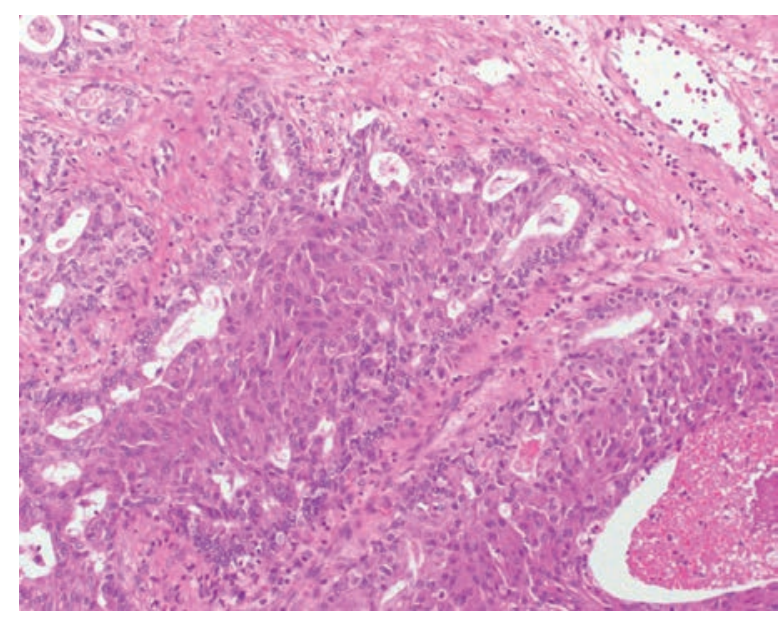

図3b 病理組織所見 (100倍 HE染色)

軽〜中等度の細胞異型を認める。

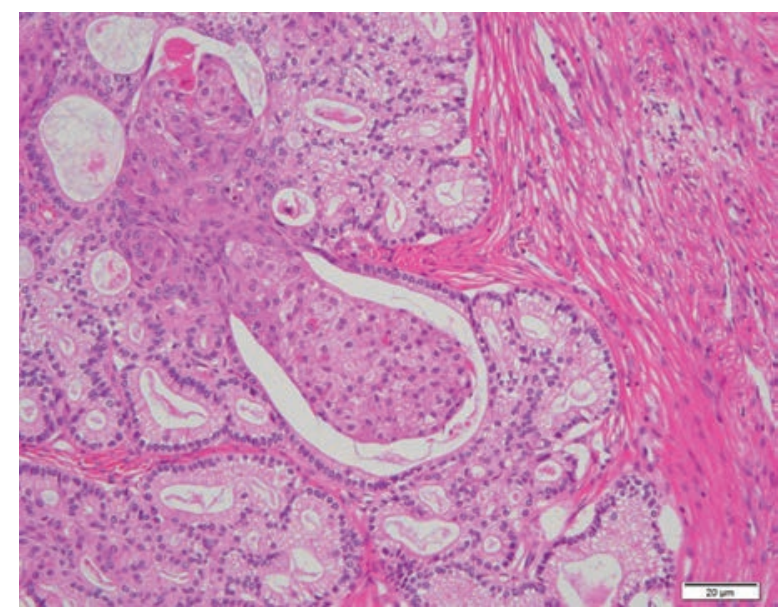

図3c 病理組織所見 (100倍 HE染色)

内膜腺は密に増殖し、高分化類内膜腺癌に匹敵するほどの構 造異型を認める。桑実様化生を伴っている。

実様化生も著明であった。一部に、平滑筋増生が 混じるAPAM様の組織像も見られた。検体の全 てがAEHの組織像で、正常な子宮内膜組織は全 く見られず、病変残存の可能性が示唆された。

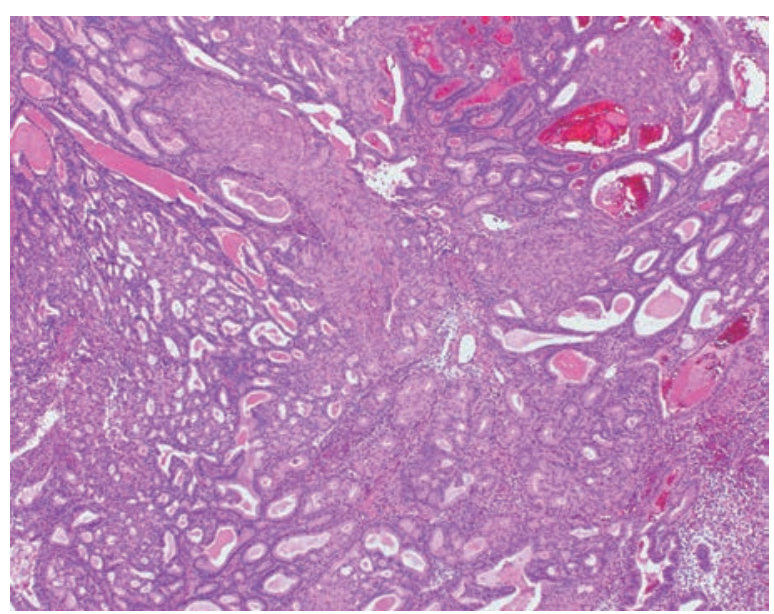

図4 病理組織所見（40倍 HE染色）

軽〜中等度の細胞異型を伴う内膜腺の広範かつ密な増殖を認 める。正常な子宮内膜組織は全く見られない。

患者は妊孕性温存を希望したため、高次施設で 高用量MPA療法を行った。その後、病変は消失 したため、当院で不妊治療を再開した。クロミフ エン療法を 3 周期施行後、体外受精を開始してい る。採卵 2 回、肧移植を 2 回施行し、現在のとこ ろ妊娠は成立していない。不妊治療中も、子宮内 膜細胞診や超音波断層法により病変再発の有無は 定期的に確認しており、ホルモン療法後 7 ケ月経 過した現在のところ再発は認めていない。

\section{【考察】}

ポリープ状異型腺筋腫 (atypical polypoid adenomyoma、APAM）は腺筋腫の変異型で、上 皮性・間葉性混合腫瘍の良性病変に属する ${ }^{2)}$ 。子 宮内腔に向かいポリープ状に突出することが多 く)、大きさは $2 \sim 6 \mathrm{~cm}$ で、比較的明瞭な腫瘤を 形成する ${ }^{4)}$ 。組織学的には、異型を示す子宮内膜 型上皮が、異型のない平滑筋成分からなる間質の 中に分布している ${ }^{2)}$ 。腺腔内に桑実様化生 morulesの形成が目立つことも特徵の一つとされ る3)。隆起性病変であるために、子宮内膜生検で 捉えやすいが、異型上皮と平滑筋成分を混じてい るために癌の筋層浸潤との鑑別を要する ${ }^{3)}$ 。好発 年齢は40歳前後で、不正性器出血で発見されるケ 一スが多く、不妊治療の際、偶然発見される場合 もある ${ }^{4)}$ 。APAM発症には、長期的または過剩な エストロゲンによる子宮内膜の過形成が関連する 可能性が指摘されている。APAMには桑実様増 殖など高エストロゲン状態による影響と考えられ る組織像が頻繁に観察される。Clementらはター ナー症候群の患者に長期的にエストロゲン投与を 行った後に出現したAPAMの 2 症例を報告し 
た ${ }^{5)}$ 。エストロゲンは子宮内膜増殖症や類内膜腺 癌の発症に重要な役割を果たしており、APAM と共通の病因が関わっていると考えられる ${ }^{6)}$ 。 Heatleyの系統的レビューによると $、$ APAM 136 例中、12例（8.8\%）で背景に子宮内膜増殖症を認 めた。また、12例（8.8\%）に子宮内膜癌の併存を 認め、そのうち 3 例では隣接した子宮内膜に癌を 認め、残りの 9 例で癌はAPAM内またはその基 部に位置していた。

本症例は若年不妊患者であり、不妊治療を契機 にAPAMとAEHが発見された。月経不順があり、 持続的なエストロゲン刺激がAPAMおよびAEH 発症に関与した可能性が示唆される。APAMの MRI画像所見として、T2強調像で低信号を示す ポリープ状腫瘤のなかに点状高信号の散在を認め ること、不規則な増強効果を認めることが特徵と される ${ }^{8.9)}$ 。本症例の診断において、MRI所見で腫 瘤は子宮内膜より低信号で、増強効果を認めるも のの小さな腺腔構造がみられなかったことから、 術前診断では子宮内膜ポリープを疑い、鑑別診断と してAPAMを挙げていなかった。また、子宮内膜細 胞診が陰性であったため、Chemical curettageを目 的とした中用量ピル投与を行ったが、組織診の重 要性を改めて認識させられた。

APAMは比較的まれでありその病態について も不明なことが多く、適切な管理法は確立してい ない。比較的若年者で未産婦・不妊症患者が多い ため、子宮温存を希望する場合が多く、取り扱い に苦慮する ${ }^{9)}$ 。

Longacreらの報告では ${ }^{10)}$ 、55例のAPAM症例 のうち、26例（47.3\%）に初回治療として子宮全 摘が行われた。残りの 29 例（52.7\%）に子宮内膜 全面掻爬またはポリペクトミーを行った後、プロ ゲステロン製剤が投与された。

松元らは、JCOG婦人科腫瘍グループ参加施設 において診断・治療されたAPAM症例29例を集 積・解析した ${ }^{11)}$ 。9 例（31.0\%）は子宮内膜全面 掻爬、2 例 (6.9\%) は経臸的切除、10例 (34.5\%) はTCR、8例（27.6\%）は子宮全摘を行った。

APAMの妊孕性温存療法が子宮内膜全面掻爬 やポリペクトミーであった時代の過去の文献では 病変持続・再発率は高く ${ }^{12)}$ 、Longacreによると 29例中13例 $(44.8 \%)^{10)}$ 、Heatleyのレビューでは

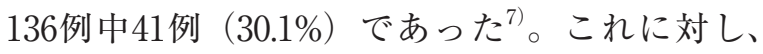
松元らの報告では、妊孕性を温存した 21 例中 5 例 （23.8\%）に再発を認めた ${ }^{11)} 。$ 再発率はTCRで10\% (1/10)、その他の治療法で36.4\% (4/11) であった。
TCRでの再発率が低いことから、TCRによる直 視下の確実な病変切除が再発率低下に寄与してい る可能性があり、妊孕性温存を希望する患者に扔 いては、TCRによる治療が推奨される ${ }^{10)}$ 。

Longacreらの報告したAPAM 55例では ${ }^{10)} 、 25$ 例 (45\%) が高分化癌との鑑別が困難な著しい構 造異型を示していた。構造異型の目立たない APAMでは筋層浸潤は見られず、局所切除後の 再発率が33\%であったのに対し、構造異型の強い APAMでは20\%に筋層への表層浸潤を認め、局所 切除後の再発率は60\%と高かった。Longacreらは このような構造異型の著しいAPAMをAPA of low malignant potential (APA-LMP) と分類した。

今回の症例はAEHを合併しており、妊孕性温 存を希望したため、黄体ホルモン療法を行った。 APA-LMPとAEHが併存しているため、癌のリス クを念頭においた厳重なフォローアップが必要と 考えている。

松元らのAPAM29例の報告では ${ }^{11)}$ 、初回治療 後、観察期間中（1～202 ケ月、平均39.6ヶ月）、 すべての患者が生存している。Longacreらの報 告では ${ }^{10)}$ 、APAM 55例のうち追跡可能であった 54例は、診断後 $1 \sim 112$ ヶ月間（平均25.2ヶ月）、 すべて生存しており子宮外再発は認めていない。 また、妊孕性温存 29 症例のうち 5 例 (17.2\%) が 妊娠・正期産に至った。このうち 4 例の組織型は APA-LMPであった。筋層浸潤のリスクを有し、 再発率の高いAPA-LMPにおいても、子宮温存は 容認されうると考えられる。妊孕性温存にあたっ ては、癌併存の有無を精查し、十分な説明を行っ たうえで患者が強く子宮温存を希望した症例に限 るべきである。子宮温存療法を選択した場合は確 実なフォローアップを行い、再発に注意して経過 観察していくことが重要と考える。

\section{【結 論】}

未産婦・不妊症患者に子宮腔内異常所見を認め る場合は、APAMも鑑別診断に挙げて精査する 必要があると考えられた。

APAMは時に子宮体癌に匹敵する著しい構造 異型を示したり筋層浸潤を認めたりするものの、 APAMによる死亡例の報告はない。子宮体癌に おいて症例を限って妊孕性温存療法が許容される ならば、APAMに関しても常に癌併存の可能性 を考慮しつつ、子宮温存に努める必要があると考 える。直視下に病変を確認・切除できるTCRは 妊孕性温存療法において特に有用であると考えら 
れる。

本論文の要旨は第 53 回日本産科婦人科内視鏡学

会において発表した。

\section{<引用文献 $>$}

1) Bosteels J, et al.: Hysteroscopy for treating subfertility associated with suspected major uterine cavity abnormalities (Review). Cochrane Database Syst Rev. $2013 ; 31: 1$.

2) 日本産科婦人科学会：4. 組織分類と診断基準、子 宮体癌取扱い規約第 3 版、2012；57、金原出版.

3 ) 向井 清、真鍋俊明、深山正久編 : 25 子宮体部、外 科病理学 [第 4版]、2006；1104-1105、文光堂.

4 ）高橋千絵、他：Atypical polypoid adenomyomaの子 宮鏡所見、日産婦内視鏡学会、2004；20 (1)：184186.

5 ）川崎彰子、他：不妊治療目的に子宮鏡下切除した子 宮内膜ポリープがAtypical polypoid adenomyomaと 診断された症例、日産婦内視鏡学会、2011；27 (2)： 433-437.

6 ) Horita A, et al.: Coexistent atypical polypoid adenomyoma and complex atypical endometrial hyperplasia in the uterus. Diagn Cytopathol 2010 ; $38: 527-532$.

7 ) Heatley MK: Atypical polypoid adenomyoma: a systematic review of the English literature. Histopathology 2006 ; 48 : 609-610.

8 ) Yamashita Y, et al.: MR imaging of atypical polypoid adenomyoma. Comput Med Imaging Graph. 1995 ; 19 : 351-355.

9 ）馬場 長、小西 郁生: 子宮ポリープ状異型腺筋腫 (atypical polypoid adenomyoma、APAM) の取り扱 い、産婦の進歩、 $2011 ； 63$ (2) : 197-201.

10) Longacre TA, et al.: Atypical polypoid adenomyofibromas (atypical polypoid adenomyomas) of the uterus. A clinicopathologic study of 55 cases. Am J Surg Pathol $1996 ; 20$ : 1-20.

11) Matsumoto $T$, et al.: Clinical management of atypical polypoid adenomyoma of the uterus. A clinicopathological review of 29 cases. Gynecol Oncol $2013 ; 129:$ 54-57.

12）井上佳代、他：妊孕能温存治療を行った若年者 atypical polypoid adenomyoma (APAM) の 2 例、 産婦の進歩、2012；64 (4)：483-489. 